\title{
A Huge Dacryolith Presenting as a Mass of the Inferior Meatus
}

\author{
Sung Tae Seo ${ }^{1}$, Ji Soo Park ${ }^{1}$, Yong Min Kim ${ }^{1,2}$, and Ki-Sang Rha ${ }^{1,2}$ \\ ${ }^{1}$ Department of Otorhinolaryngology-Head and Neck Surgery, ${ }^{2}$ Research Institute of Medical Science, \\ Chungnam National University School of Medicine, Daejeon, Korea
}

하비도의 종물로 보였던 거대한 누석

서성태 ${ }^{1} \cdot$ 박지수 $^{1} \cdot$ 김용민 ${ }^{1,2} \cdot$ 나기상 $^{1,2}$

충남대학교 의학전문대학원 이비인후과학교실, ${ }^{1}$ 의학연구소 ${ }^{2}$

\author{
Received April 17, 2015 \\ Revised June 3, 2015 \\ Accepted June 3, 2015 \\ Address for correspondence \\ Ki-Sang Rha, MD, PhD \\ Department of Otorhinolaryngology- \\ Head and Neck Surgery, \\ Chungnam National University \\ School of Medicine, \\ 282 Munhwa-ro, Jung-gu, \\ Daejeon 35015, Korea \\ Tel +82-42-280-7698 \\ Fax +82-42-253-4059 \\ E-mail ksrha@cnu.ac.kr
}

A dacryolith is a concretion within the lacrimal drainage system. Although it may cause intermittent epiphora without inflammation, dacryoliths are often underlying contributors to recurrent or chronic dacryocystitis. It may occur anywhere along the lacrimal drainage system, albeit most commonly in the lacrimal sac. We report an interesting case of a dacryolith presenting as a mass of inferior meatus, which was managed via endonasal endoscopic approach. Korean J Otorhinolaryngol-Head Neck Surg 2016;59(3):238-41

Key Words Dacryocystorhinostomy $\cdot$ Lacrimal duct obstruction.

\section{Introduction}

Dacryoliths are one of the causes of primary acquired nasolacrimal duct obstruction. ${ }^{1-3)}$ Although dacryoliths can form anywhere along the lacrimal drainage system from the canaliculi to the nasolacrimal duct, it is very rare for them to present as a mass of the inferior meatus. We report an unusual case of a dacryolith occupying the whole lacrimal drainage system and protruding into the inferior meatus through the nasolacrimal duct orifice.

\section{Case}

A 35-year-old male was referred to our department due to a mass of the inferior meatus found at the private ENT clinic. He had 3-month history of recurrent left-sided epiphora and pain at the inner canthus. He had been treated for apparent dacryo- cystitis with oral antibiotics and ophthalmic drops by an ophthalmologist. However, his symptoms waxed and waned.

On examination, there was no erythema or edema in the medial canthal region. The lacrimal drainage system was freely patent to saline irrigation through the canaliculi. However, rigid nasal endoscopy revealed the presence of a yellowish, puttylike mass in the inferior meatus (Fig. 1). This mass occupying the Hasner's valve area was suspected of causing nasolacrimal duct obstruction. CT scanning showed a dilation of the left lacrimal sac and nasolacrimal duct with a soft tissue mass (Fig. 2A) and a mass in the inferior meatus (Fig. 2B). A clinical diagnosis of dacryolith was made based on the patient's symptoms and endoscopic and radiologic findings.

Endonasal endoscopic surgery was performed by a rhinologist. At first, we attempted to remove the mass through the inferior meatus. However, complete evacuation of the mass impacted in the nasolacrimal duct and lacrimal sac was not 
achieved despite repeated probing and massive saline irrigation through the canaliculi. Eventually, we performed endoscopic dacryocystorhinostomy (DCR) with extension into the nasolacrimal duct. After the lacrimal sac and nasolacrimal duct along its whole length were opened, the dacryolith was removed completely. Grossly, the specimen was smooth-surfaced, soft, and pliant in consistency. Its length was about 3.5 $\mathrm{cm}$ (Fig. 3). The specimen was stained with hematoxylin and eosin, periodic acid-Schiff (PAS), and Grocott's methenamine silver. The hematoxylin and eosin-stained section revealed acellular amorphous eosinophilic material with scattered vacu-

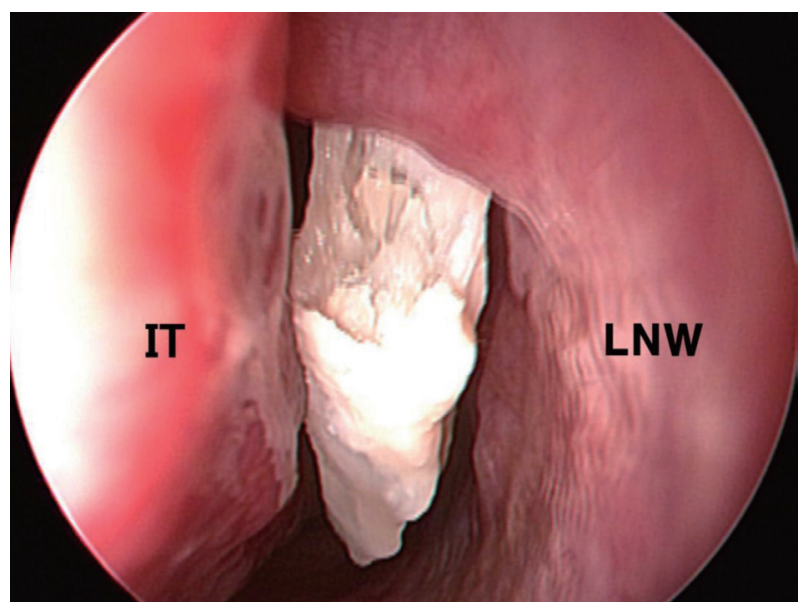

Fig. 1. Endoscopic view of the left inferior meatus demonstrating a 7-mm, yellowish putty-like mass obstructing the nasolacrimal duct orifice. IT and LNW indicate inferior turbinate and lateral nasal wall, respectively.

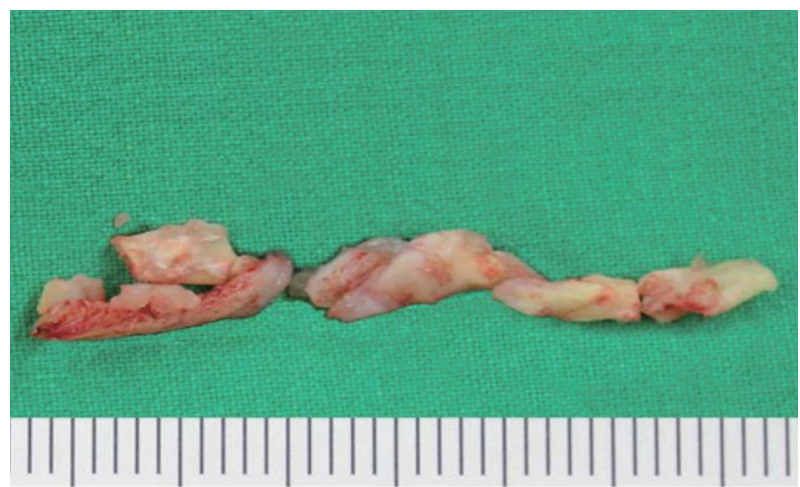

Fig. 3. Gross image of the dacryolith, measuring approximately $3.5 \mathrm{~cm}$ in length.

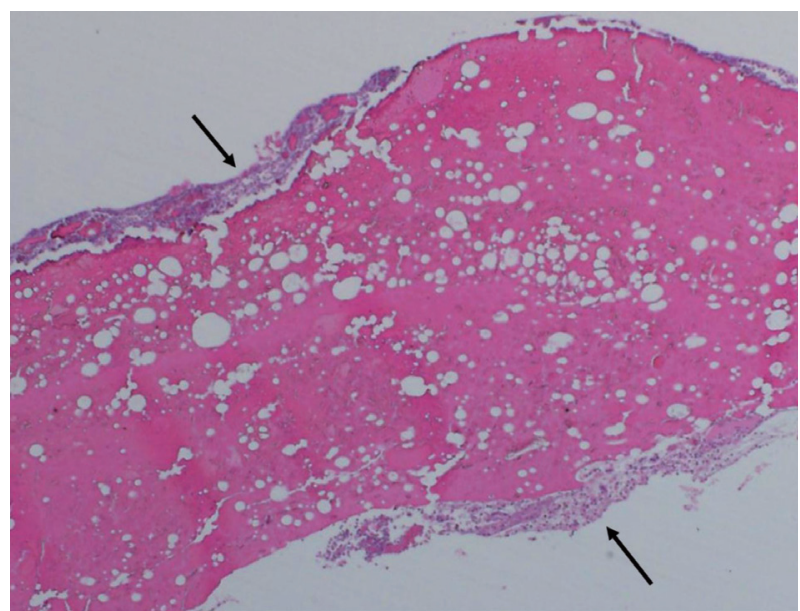

Fig. 4. Light micrograph showing acellular amorphous eosinophilic material with many scattered vacuoles (hematoxylin-eosin, $\times 40$ ). Note the surface inflammation (black arrows).
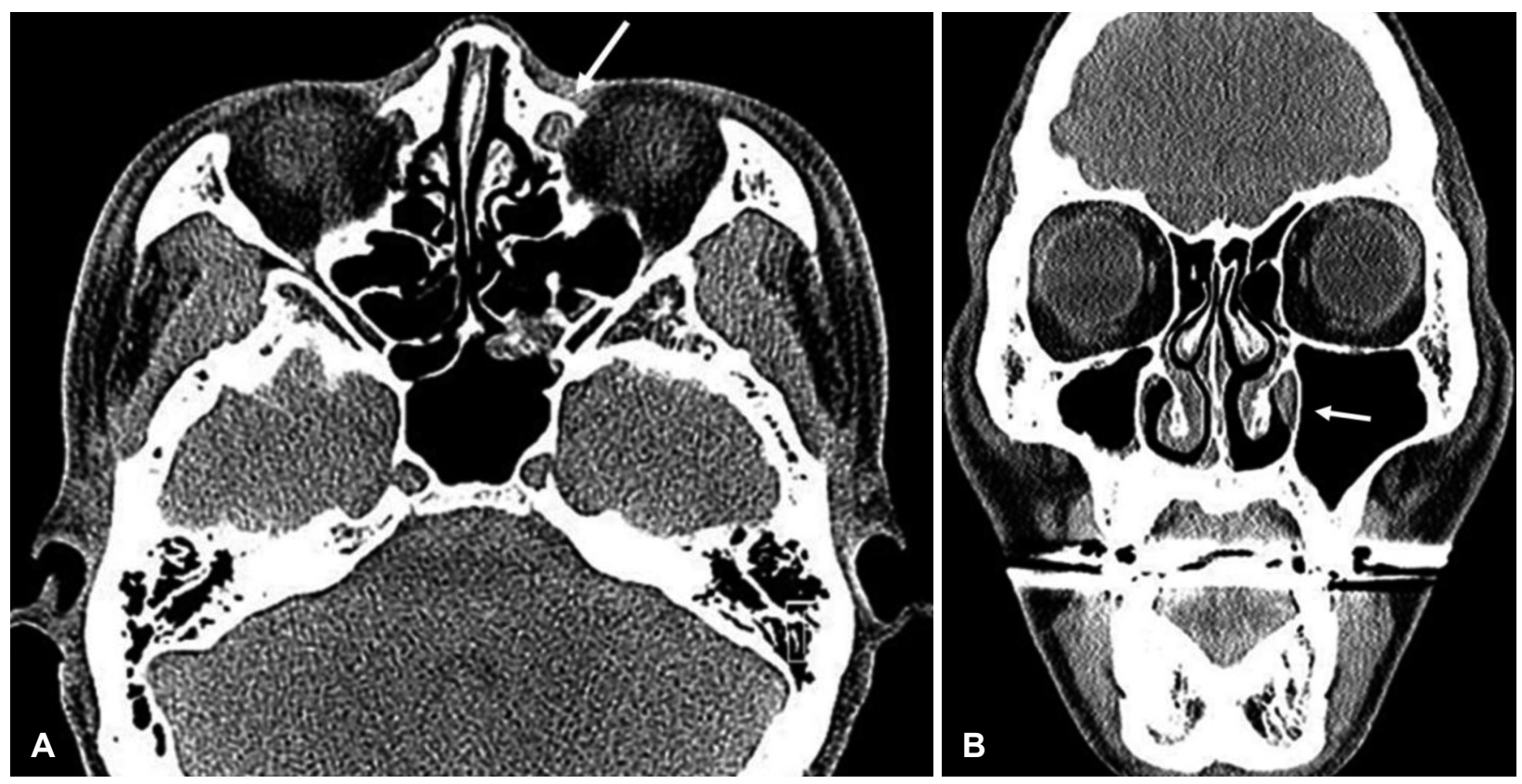

Fig. 2. Axial CT image obtained at the level of the orbits showing a dilation of the left lacrimal sac with a heterogenous density mass (white arrow) (A). A coronal CT image showing a mass in the left inferior meatus (white arrow) (B). 
oles throughout the mass (Fig. 4). The material stained moderately intensely with PAS. Bacteria or fungal hyphae were not found along the surfaces of the mass.

The patient's epiphora improved immediately. Three months later, the lacrimal sac and nasolacrimal duct were widely opened and the patient was free of symptoms.

\section{Discussion}

A dacryolith is a cast of putty-like consistency in the shape of the lacrimal sac or duct. Dacryoliths are usually small, mostly less than $1 \mathrm{~cm}^{4,5)}$ They are found most commonly in the lacrimal sac during DCR. However, they may occur in any part of the nasolacrimal drainage system. ${ }^{3)}$ Rogers and DelGaudio $^{6}$ reported one case of a dacryolith in the inferior meatus, easily removed endoscopically in the office. Our case also presented with a mass in the inferior meatus, but it was too large (about $3.5 \mathrm{~cm}$ in length) to remove via the inferior meatus. Complete evacuation failed despite repeated probing and massive saline irrigation through the canaliculi. The dacryolith occupied the whole lacrimal drainage system from the lacrimal sac to the nasolacrimal duct. Therefore, we performed endoscopic DCR with extension into the nasolacrimal duct to remove the dacryolith.

Dacryoliths become symptomatic when they block the lacrimal drainage system. Interestingly, dacryoliths occur more often in patients with partial obstruction rather than complete obstruction. ${ }^{2,3)}$ Our patient showed a patent nasolacrimal drainage system when irrigated with saline through the canaliculi. Thus, free irrigation to the nose does not exclude dacryolith as the cause of occlusion.

Diagnosis of a dacryolith is usually made incidentally, either when a cast is found in the lacrimal sac during DCR or when the dacryolith passes spontaneously into the nasal cavity. ${ }^{7,8)}$ However, clinical suspicion of a dacryolith should arise when symptoms are recurrent or chronic. Conventional dacryocystography may detect a dacryolith, seen as a filling defect in the lacrimal sac. CT scanning may also be a useful tool in diagnosing a dacryolith preoperatively. ${ }^{9)}$ In addition, judging from our experience, preoperative endonasal endoscopic examination may be necessary in cases of recurrent epiphora to rule out intranasal abnormalities and to assess the state of the nasolacrimal duct orifice.

Although the history of dacryoliths is long, their pathophysiology is still largely unknown. Several predisposing factors related to dacryolith formation have been suggested, such as chronic obstruction and inflammation of the lacrimal sac, facial trauma, bacterial or fungal infection, a foreign body such as an eyelash, cigarette smoking, congenital anomalies of the Hasner's valve, dehydration, and alterations in the rheology and flow of tears. ${ }^{1,2,510-12)}$ Recently, several investigators have demonstrated that dacryoliths are predominantly composed of organic material, with limited inorganic contribution. ${ }^{5,12)}$ Paulsen, et al. ${ }^{2)}$ demonstrated that dacryoliths consist of large amounts of trefoil factor family (TFF) peptides and mucins and hypothesized that increased production of TFF peptides and mucins may play a functional role in dacryolith formation.

Recently, Perry, et al. ${ }^{12)}$ proposed abandoning the term "dacryolith" because of the absence of significant calcium or stonelike density in these masses. Instead, they recommended the adoption of the term "concretion." They divided lacrimal drainage system concretions into two major forms: mucopeptide and bacterial. The two types of concretions showed differences in location and histopathological composition. Bacterial concretions were found chiefly in the canaliculus and were composed of large matted masses of filamentous, presumed Actinomyces organisms, while mucopeptide concretions were found exclusively within the lacrimal sac and were composed of compacted lamellations of amorphous acellular eosinophilic material punctuated by small vacuoles. The concretion of our case was consistent with mucopeptide concretion.

Although spontaneous expulsion has been reported and nonsurgical interventions are feasible alternatives, the treatment of choice is surgical removal of the dacryolith and restoration of the nasolacrimal system. In recent years, endonasal endoscopic DCR has become the treatment of choice for nasolacrimal system obstruction. Thus, rhinologists should play an important role in the diagnosis and treatment of nasolacrimal duct obstruction because rhinologists are familiar with the use of endoscope.

\section{REFERENCES}

1) Paulsen FP, Berry MS. Mucins and TFF peptides of the tear film and lacrimal apparatus. Prog Histochem Cytochem 2006;41(1):1-53.

2) Paulsen FP, Schaudig U, Fabian A, Ehrich D, Sel S. TFF peptides and mucins are major components of dacryoliths. Graefes Arch Clin Exp Ophthalmol 2006;244(9):1160-70.

3) Yazici B, Hammad AM, Meyer DR. Lacrimal sac dacryoliths: predictive factors and clinical characteristics. Ophthalmology 2001; 108(7):1308-12.

4) Komínek P, Červenka S, Zeleník K, Pniak T, Tomášková H, Matoušek P. Lacrimal sac dacryolith (76 cases): a predictive factor for successful endonasal dacryocystorhinostomy? Eur Arch Otorhinolaryngol 2014;271(6):1595-9.

5) Iliadelis ED, Karabatakis VE, Sofoniou MK. Dacryoliths in a series of dacryocystorhinostomies: histologic and chemical analysis. 
Eur J Ophthalmol 2006;16(5):657-62.

6) Rogers GA, DelGaudio JM. Inferior meatus dacryolith: an easily managed cause of epiphora. Arch Otolaryngol Head Neck Surg 2008; 134(10):1110-1.

7) Kaye-Wilson LG. Spontaneous passage of a dacryolith. Br J Ophthalmol 1991;75(9):564.

8) Rosen WJ, Rose GE. Intranasal passage of dacryoliths. Br J Ophthalmol 2000;84(7):799-800.

9) Asheim J, Spickler E. CT demonstration of dacryolithiasis complicated by dacryocystitis. AJNR Am J Neuroradiol 2005;26(10):2640-1.

10) Repp DJ, Burkat CN, Lucarelli MJ. Lacrimal excretory system concretions: canalicular and lacrimal sac. Ophthalmology 2009;116 (11):2230-5.

11) Andreou P, Rose GE. Clinical presentation of patients with dacryolithiasis. Ophthalmology 2002;109(8):1573-4.

12) Perry LJ, Jakobiec FA, Zakka FR. Bacterial and mucopeptide concretions of the lacrimal drainage system: an analysis of 30 cases. Ophthal Plast Reconstr Surg 2012;28(2):126-33. 